\title{
Patterns of Retinal Ganglion Cell Damage in Neurodegenerative Disorders: Parvocellular vs Magnocellular Degeneration in Optical Coherence Tomography Studies
}

\author{
Chiara La Morgia ${ }^{1,2 *}$, Lidia Di Vito ${ }^{1}$, Valerio Carelli ${ }^{1,2}$ and Michele Carbonelli ${ }^{1}$ \\ ${ }^{1}$ IRCCS Institute of Neurological Sciences of Bologna, Bellaria Hospital, Bologna, Italy, ${ }^{2}$ Neurology Unit, Department of \\ Biomedical and Neuromotor Sciences, University of Bologna, Bologna, Italy
}

OPEN ACCESS

Edited by:

Andrzej Grzybowski,

University of Warmia and Mazury in

Olsztyn, Poland

Reviewed by:

Giacinto Triolo,

San Raffaele Hospital (IRCCS), Italy

Inigo Gabilondo,

BioCruces Health Research Institute,

Spain

${ }^{*}$ Correspondence:

Chiara La Morgia

chiara.lamorgia@unibo.it,

chiaralamorgia@gmail.com

Specialty section:

This article was submitted to

Neuro-Ophthalmology,

a section of the journal

Frontiers in Neurology

Received: 20 September 2017 Accepted: 08 December 2017 Published: 22 December 2017

Citation:

La Morgia C, Di Vito L, Carelli V and Carbonelli M (2017) Patterns of

Retinal Ganglion Cell Damage in Neurodegenerative Disorders:

Parvocellular vs Magnocellular Degeneration in Optical Coherence

Tomography Studies.

Front. Neurol. 8:710.

doi: 10.3389/fneur.2017.00710
Many neurodegenerative disorders, such as Parkinson's disease (PD) and Alzheimer's disease (AD), are characterized by loss of retinal ganglion cells (RGCs) as part of the neurodegenerative process. Optical coherence tomography (OCT) studies demonstrated variable degree of optic atrophy in these diseases. However, the pattern of degenerative changes affecting the optic nerve $(\mathrm{ON})$ can be different. In particular, neurodegeneration is more evident for magnocellular RGCs in AD and multiple system atrophy with a pattern resembling glaucoma. Conversely, in PD and Huntington's disease, the parvocellular RGCs are more vulnerable. This latter pattern closely resembles that of mitochondrial optic neuropathies, possibly pointing to similar pathogenic mechanisms. In this review, the currently available evidences on OCT findings in these neurodegenerative disorders are summarized with particular emphasis on the different pattern of RGC loss. The ON degeneration could become a validated biomarker of the disease, which may turn useful to follow natural history and possibly assess therapeutic efficacy.

Keywords: optic nerve, retinal ganglion cells, optical coherence tomography, Parkinson's disease, Alzheimer's disease, Huntington's disease, glaucoma, multiple system atrophy

\section{INTRODUCTION}

Many neurodegenerative disorders are characterized by increasing evidences that optic nerve (ON) degeneration is part of the central nervous system neurodegenerative process. In fact, optical coherence tomography (OCT) and histological postmortem studies documented loss of retinal ganglion cells (RGCs) and their ON-forming axons in neurodegenerative disorders such as Alzheimer's disease (AD) (1-4), Parkinson's disease (PD) (5), Huntington's disease (HD) (6), multiple system atrophy (MSA) $(7,8)$, spinocerebellar ataxias $(9)$, spastic paraparesis (10), and others.

Retinal ganglion cells are neurons located in the retinal ganglion cell layer (GCL) characterized by a soma from which the originating axon runs initially in the retinal nerve fiber layer (RNFL). Then, these axons converge turning into the optic disc, cross the lamina cribrosa at the optic nerve head $(\mathrm{ONH})$, and constitute the $\mathrm{ON}$. They are particularly sensitive to neurodegenerative damage due to 
defective mitochondrial dynamics and axonal transport, as well as oxidative stress and energy depletion, given the high metabolic demand and performances typical of these cells, mostly determined by the asymmetric myelination $(11,12)$.

Moreover, the deposition in RGCs of $\alpha$-synuclein and $\beta$-amyloid $(A \beta)$, typical hallmarks of these neurodegenerative disorders, has been already documented, respectively, in PD $(13,14)$ and $\operatorname{AD}(2,15,16)$.

Interestingly, the pattern of RGC loss described in these neurodegenerative disorders can be different. In fact, the axonal damage in $\mathrm{AD}$ is described as typically affecting the magnocellular cells (M-cells), which is reflected by a preferential RNFL thinning in the superior and inferior quadrants (17). This pattern of RGC loss, which is also reported in $\operatorname{MSA}(7,8)$, resembles that described in glaucoma, where a preferential loss of M-cells is established (18).

Conversely, RGC loss in PD involves preferentially the parvocellular cells (P-cells), which is reflected by the temporal thinning of the RNFL (17). This pattern is similar to what is described for mitochondrial optic neuropathies, where typically the pathology affects the papillomacular bundle (PMB) and is hallmarked by the preferential loss of the P-cells leading to temporal pallor of the optic disc and a central visual field defect $(11,19)$.

This review is aimed at critically highlighting the differential pattern of RGC loss in some paradigmatic neurodegenerative disorders such as $\mathrm{AD}$ and $\mathrm{PD}$, based on the main OCT and histological findings derived by literature.

\section{RGC FEATURES}

Visual information generated by photoreceptors is transmitted through bipolar cells to RGCs, whose axons leave the eye reaching the lateral geniculate nucleus (LGN). At least 30 different morphological types of RGCs have been recognized in the human retina, but only some of them are judged essential for the function of the four different visual pathways (20).

The midget RGCs (about $80 \%$ of total RGCs in the monkey retina) project to the parvocellular layers of the LGN, the parasol RGCs (5-15\%) project to the magnocellular layers of the LGN, the bistratified RGCs form part of the koniocellular visual pathway projecting to the koniocellular layers of the LGN, and finally the melanopsin-containing RGCs (mRGCs, about $1 \%$ of total RGCs) project mostly to the suprachiasmatic nucleus of the hypothalamus, constituting the retino-hypothalamic pathway.

RGCs are characterized by specific common features, such as the location of their somata in the GCL, the arborization of their dendrites in the inner plexiform layer (IPL), and the gathering of their axons in the ON, which, by projecting to the LGN, connect their glutamatergic synapsis with the second order neurons of the visual pathway (21).

An important characteristic of the P-pathway is the existence of very small midget cells (or P-cells) that are connected to single-cone midget bipolar cells in the central $2 \mathrm{~mm}$ around the fovea $(22,23)$. This one-to-one neuronal circuitry is thought to form the basis of red-green color opponency. The parasol cells (or M-cells) constitute a smaller proportion of RGCs and their long (L) and middle (M) wavelength-sensitive cone inputs form the magnocellular pathway, which transmits achromatic visual information of high temporal but low spatial resolution and luminance and movement messages (24). The M-cells of primates have peculiar features represented by large cell bodies, thick axons, and wide radial branching dendritic trees. At difference, P-cells have small cell bodies, thin axons, and narrow dendritic trees with a more bushy and dense branching pattern (25). Moreover, large fibers exhibit faster pulse conduction than the smaller fibers (26).

Both RGC classes increase in size with increasing distance from the foveal slope, maintaining their distinct branching pattern at all eccentricities, but the average P-cell dendritic-field diameter is smaller than mean $\mathrm{M}$-cell dendritic field throughout the retina.

At the ONH, RGC axons are distributed in a specific topographic manner (27). In fact, the retinal nerve fibers from the nasal half of the retina step directly into the optic disc as superior and inferior radiating fibers, fibers from the macular area come horizontally as $\mathrm{PMB}$, and fibers from the temporal retina arch above and below the macula as superior and inferior arcuate fibers (27).

The above described anatomy of the P-pathway (one-to-one connection with bipolar cells in the central $2 \mathrm{~mm}$ around the fovea and the conveyance of color information) implies that the P-cells are predominantly represented by $\mathrm{PMB}$ entering the $\mathrm{ONH}$ from the temporal quadrant. Furthermore, topographically, deeper fibers from peripheral retina occupy peripheral location in the $\mathrm{ONH}$ (neighboring to the ONH edge), and superficial fibers from central retina occupy central location in the ONH (Figure 1A). Therefore, in the retro-laminar region of the ON, the axons from PMB (predominantly formed by p-RGCs) are arranged temporally in the nerve but along the path to the LGN, they gradually shift centrally, whereas larger fibers (predominantly formed by p-RGCs) are located in greater proportion in the periphery of the nerve (28) (Figure 1B).

\section{OCT FINDINGS IN NEURODEGENERATIVE DISEASES WITH PREFERENTIAL PARVOCELLULAR DAMAGE}

\section{Parkinson's Disease}

Parkinson's disease is a neurodegenerative disease whose core clinical features are bradykinesia, resting tremor or rigidity, and response to L-DOPA therapy (29). PD prevalence increases with age, which is the single most relevant risk factor (30). Visual disturbances described in PD may range from reduced visual acuity and color vision to abnormal contrast sensitivity, dysfunction of eye movements and visual hallucinations $(31,32)$.

Moreover, the occurrence of $\mathrm{ON}$ pathology is reported by numerous OCT studies including time-domain and spectraldomain studies (33-56) (Table 1).

Interestingly, the pattern of axonal loss reported by OCT studies points toward a preferential involvement of the temporal quadrant $(5,33,38,41-43,48,49,52,53,57)$. Moreover, the evidence of a more severe RGC loss in the eye contralateral to the most affected body side is suggestive of a congruently asymmetric degenerative process in PD (42). This pattern of axonal loss is clearly distinguishable from the preferential loss 


\section{A}
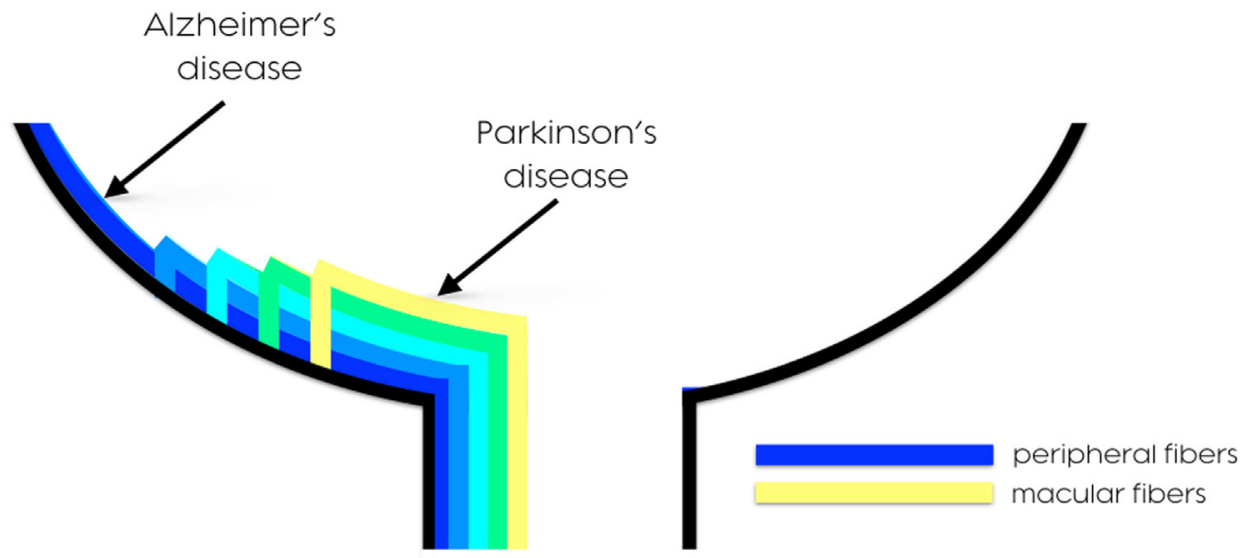

B

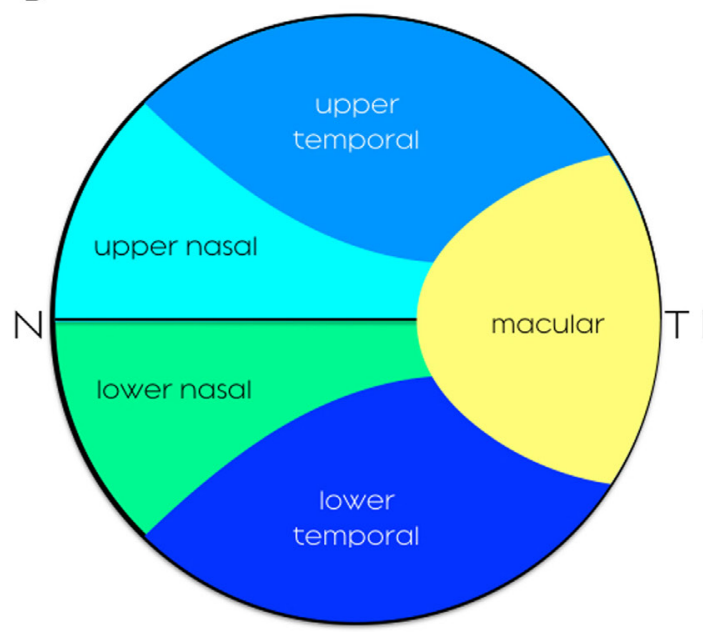

Arrandement of
fibers in $\mathrm{ONH}$

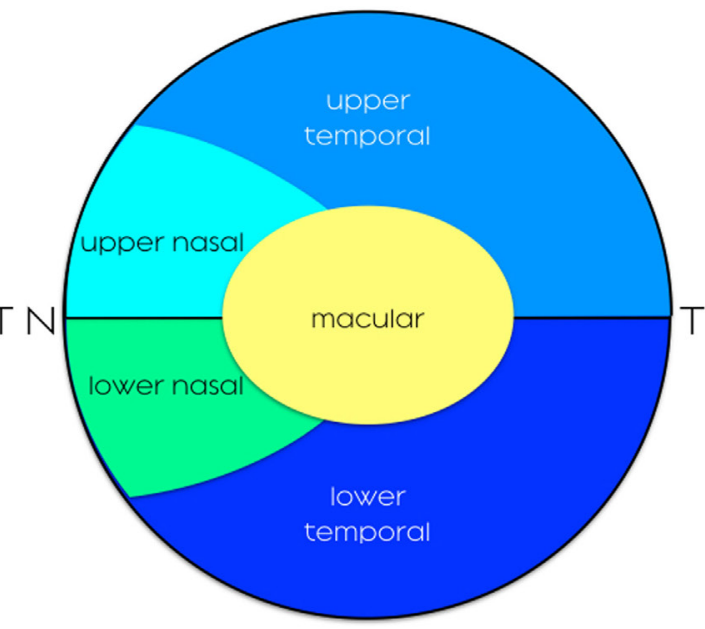

Arrangement of fibers in
retrolaminar $\mathrm{ON}$

FIGURE 1 | (A) Distribution of retinal nerve fibers. Cross-sectional arrangement of axons, with deeper fibers originating from peripheral retina running closer to choroid occupying peripheral location in $\mathrm{ONH}$, and superficial fibers originating nearer to the ONH occupy a more central portion of the nerve. (B) Arrangement of nerve fibers in the anterior visual pathway. In the pre-laminar, laminar, and proximal retro-laminar region of the $\mathrm{ON}$, the axons from PMB are arranged temporally in the nerve but along the path to the LGN, they gradually shift centrally. ON, optic nerve; ONH, optic nerve head; PMB, papillomacular bundle; LGN, lateral geniculate nucleus.

of M-cells documented in other parkinsonian syndromes such as MSA $(7,8)$ and resembles mitochondrial optic neuropathies (11). The most common mitochondrial optic neuropathies, i.e., Leber's hereditary optic neuropathies (LHON) and dominant optic atrophy (DOA) are, in fact, typically characterized by ON pathology involving preferentially the smallest axons constituting the PMB leading to temporal pallor and central scotoma $(11,19)$. The P-cells are energetically more vulnerable to mitochondrial dysfunction, as clearly described by recent histological studies and mathematical modeling of the RGC loss in LHON (58). This susceptibility to mitochondrial dysfunction and particularly to oxidative stress may be related to the high energetic demand in relation to a low energetic potential, which is due to the high surface area/volume ratio, and to the absence of myelin around the axons in the unmyelinated portion of the $\mathrm{ON}$ (58).
In this context, the similar pattern of axonal loss in the ON characterizing PD and mitochondrial optic neuropathies has a common ground in the documented complex I defect and, more in general, mitochondrial dysfunction reported in PD (59).

Moreover, in PD eyes, it has been demonstrated that the area around the fovea, where INL and GCL emerge, is characterized by a significant remodeling as consequence of the neurodegeneration involving the inner nuclear layers and has been indicated as a marker of the disease with the best discriminative power compared with controls (60). Interestingly, as for the RNFL results reported by OCT studies (42), it has been described an interocular asymmetry for the foveal thickness, pointing again to an asymmetry of the neurodegenerative process in PD, congruent with the motor symptoms of the disease (61). Finally, recent studies demonstrated the presence of $\alpha$-synuclein deposition in 
TABLE 1 | OCT results in PD.

\begin{tabular}{|c|c|c|c|}
\hline & OCT & No. of patients & Results \\
\hline $\begin{array}{l}\text { Inzelberg } \\
\text { et al. (33) }\end{array}$ & Zeiss 3000 Stratus & $\begin{array}{l}10 \text { PD } \\
10 \text { controls }\end{array}$ & $\begin{array}{l}\downarrow \text { avg; inf-temp } \\
\text { RNFL thickness }\end{array}$ \\
\hline $\begin{array}{l}\text { Yavas } \\
\text { et al. (34) }\end{array}$ & $\begin{array}{l}\text { Heidelberg Retinal } \\
\text { Tomography }\end{array}$ & $\begin{array}{l}44 \mathrm{PD} \\
21 \text { controls }\end{array}$ & $\begin{array}{l}\downarrow \text { avg; nasal, sup } \\
\text { and inf-nas, and } \\
\text { inf-temp RNFL } \\
\text { thickness }\end{array}$ \\
\hline $\begin{array}{l}\text { Altintaş } \\
\text { et al. (35) }\end{array}$ & Zeiss 3000 Stratus & $\begin{array}{l}17 \text { PD } \\
11 \text { controls }\end{array}$ & $\begin{array}{l}\downarrow \text { avg; sup and nas } \\
\text { RNFL thickness }\end{array}$ \\
\hline $\begin{array}{l}\text { Moschos } \\
\text { et al. (38) }\end{array}$ & Zeiss 3000 Stratus & $\begin{array}{l}16 \text { PD } \\
20 \text { controls }\end{array}$ & $\begin{array}{l}\downarrow \text { inf and temp } \\
\text { RNFL thickness }\end{array}$ \\
\hline $\begin{array}{l}\text { Garcia-Martin } \\
\text { et al. (39) }\end{array}$ & Cirrus and Spectralis & $\begin{array}{l}75 \text { PD } \\
75 \text { controls }\end{array}$ & $\begin{array}{l}\downarrow \text { RNFL thickness } \\
\text { in all four quadrants }\end{array}$ \\
\hline $\begin{array}{l}\text { Rohani } \\
\text { et al. (40) }\end{array}$ & Topcon 3D OCT & $\begin{array}{l}27 \mathrm{PD} \\
27 \text { controls }\end{array}$ & $\begin{array}{l}\downarrow \text { avg; all quadrants } \\
\text { RNFL thickness }\end{array}$ \\
\hline $\begin{array}{l}\text { Kirbas } \\
\text { et al. (41) }\end{array}$ & Cirrus & $\begin{array}{l}42 \mathrm{PD} \\
40 \text { controls }\end{array}$ & $\begin{array}{l}\downarrow \text { avg; temp RNFL } \\
\text { thickness }\end{array}$ \\
\hline $\begin{array}{l}\text { La Morgia } \\
\text { et al. (42) }\end{array}$ & Zeiss 3000 Stratus & $\begin{array}{l}43 \mathrm{PD} \\
86 \text { controls }\end{array}$ & $\begin{array}{l}\downarrow \text { temp RNFL } \\
\text { thickness }\end{array}$ \\
\hline $\begin{array}{l}\text { Satue } \\
\text { et al. (43) }\end{array}$ & Cirrus and Spectralis & $\begin{array}{l}100 \text { PD } \\
100 \text { controls }\end{array}$ & $\begin{array}{l}\downarrow \text { inf (Cirrus and } \\
\text { Spectralis) RNFL } \\
\text { thickness }\end{array}$ \\
\hline $\begin{array}{l}\text { Sen } \\
\text { et al. (45) }\end{array}$ & $\begin{array}{l}\text { Not mentioned in the } \\
\text { abstract }\end{array}$ & $\begin{array}{l}35 \mathrm{PD} \\
11 \text { controls }\end{array}$ & $\begin{array}{l}\downarrow \text { avg RNFL } \\
\text { thickness }\end{array}$ \\
\hline $\begin{array}{l}\text { Satue } \\
\text { et al. (47) }\end{array}$ & Cirrus and Spectralis & $\begin{array}{l}153 \text { PD } \\
242 \text { controls }\end{array}$ & $\begin{array}{l}\downarrow \text { avg (Cirrus and } \\
\text { Spectralis); sup, } \\
\text { inf, and temp } \\
\text { (Cirrus); sup and inf } \\
\text { (Spectralis) RNFL } \\
\text { thickness }\end{array}$ \\
\hline $\begin{array}{l}\text { Garcia-Martin } \\
\text { et al. (48) }\end{array}$ & Cirrus and Spectralis & $\begin{array}{l}46 \mathrm{PD} \\
33 \text { control }\end{array}$ & $\begin{array}{l}\downarrow \text { avg (Cirrus and } \\
\text { Spectralis); sup, inf, } \\
\text { and temp (Cirrus); } \\
\text { sup and temp } \\
\text { (Spectralis) RNFL } \\
\text { thickness }\end{array}$ \\
\hline $\begin{array}{l}\text { Garcia-Martin } \\
\text { et al. (49) }\end{array}$ & Spectralis & $\begin{array}{l}129 \text { PD } \\
129 \text { controls }\end{array}$ & $\begin{array}{l}\downarrow \text { avg; nas-inf, } \\
\text { temp-inf, and } \\
\text { temp-sup RNFL } \\
\text { thickness }\end{array}$ \\
\hline $\begin{array}{l}\text { Jiménez } \\
\text { et al. (50) }\end{array}$ & Zeiss 3000 Stratus & $\begin{array}{l}52 \text { PD } \\
50 \text { controls }\end{array}$ & $\begin{array}{l}\downarrow \text { avg; all four } \\
\text { quadrants RNFL } \\
\text { thickness }\end{array}$ \\
\hline $\begin{array}{l}\text { Bayhan } \\
\text { et al. (51) }\end{array}$ & SD-OCT (RTVue-100) & $\begin{array}{l}20 \mathrm{PD} \\
30 \text { controls }\end{array}$ & $\begin{array}{l}\downarrow \text { nas RNFL } \\
\text { thickness }\end{array}$ \\
\hline $\begin{array}{l}\text { Sari } \\
\text { et al. (52) }\end{array}$ & SD-OCT & $\begin{array}{l}54 \text { PD } \\
54 \text { controls }\end{array}$ & $\begin{array}{l}\downarrow \text { inf and temp } \\
\text { RNFL thickness }\end{array}$ \\
\hline $\begin{array}{l}\text { Kaur } \\
\text { et al. (53) }\end{array}$ & SD-OCT & $\begin{array}{l}20 \text { PD } \\
20 \text { controls }\end{array}$ & $\begin{array}{l}\downarrow \text { avg; sup and } \\
\text { temp RNFL } \\
\text { thickness }\end{array}$ \\
\hline $\begin{array}{l}\text { Eraslan } \\
\text { et al. (55) }\end{array}$ & SD-OCT (RTVue-100) & $\begin{array}{l}25 \text { PD } \\
23 \text { controls }\end{array}$ & $\begin{array}{l}\downarrow \text { avg RNFL } \\
\text { thickness }\end{array}$ \\
\hline $\begin{array}{l}\text { Pilat } \\
\text { et al. (56) }\end{array}$ & SD-OCT (Copernicus) & $\begin{array}{l}25 \text { PD } \\
25 \text { controls }\end{array}$ & $\begin{array}{l}\downarrow \text { avg; all four } \\
\text { quadrants RNFL } \\
\text { thickness }\end{array}$ \\
\hline
\end{tabular}

PD, Parkinson's disease; avg, average; temp, temporal; sup, superior; inf, inferior; nas, nasal; RNFL, retinal nerve fiber layer; SD, spectral domain; OCT, optical coherence tomography. the retina of PD patients. This deposition is particularly evident in the inner retina including the GCL, the IPL, and the interface between IPL and inner nuclear layer $(13,14)$. Interestingly, there is a documented direct relationship between intracellular deposition of $\alpha$-synuclein and mitochondrial dysfunction (59).

\section{Huntington's Disease}

Huntington's disease is a neurodegenerative disease inherited as an autosomal dominant trait, whose main features are the occurrence of choreic movements, as well as psychiatric and cognitive disturbances in young-adult individuals (62).

Moreover, HD patients early in the disease course suffer sleep and circadian dysfunction, which contribute to the cognitive deterioration (63). The presence of retinal degeneration, and in particular of RGC loss, has been recently reported by OCT studies $(6,64)$. In particular, Kersten and coauthors demonstrated that in these patients there is a RNFL thinning in the temporal sector correlating with the disease duration, similar to PD (64). As for $\mathrm{PD}$, this axonal loss pattern may be explained by the role attributed to mitochondrial dysfunction in the pathogenesis of the disease. In particular, recent experimental evidences in HD point to an abnormal mitochondrial dynamics with defective fission $(65,66)$.

\section{OCT FINDINGS IN NEURODEGENERATIVE DISEASES WITH PREFERENTIAL MAGNOCELLULAR DAMAGE}

\section{Alzheimer's Disease}

Alzheimer's disease is the most frequent cause of dementia and is hallmarked by the accumulation of amyloid plaques and neurofibrillary tangles in the brain (67). AD is characterized by visual disturbances occurring early in the course of the disease and reflecting neuronal damage of the cerebral visual pathway. The symptoms affect various aspects of visual function such as visual field, color vision, contrast sensitivity, motion perception, visuospatial construction, visual attention, and fixation (68).

Several histological studies in $\mathrm{AD}$ demonstrated the impairment of the entire visual pathway, documented initially in the brain and subsequently in the retina and ON (69-75). In 1986, Hinton and colleagues provided the first evidences of optic neuropathy in $\mathrm{AD}$, describing loss of RGCs and axons at postmortem histology of the ON (1). Subsequently, other histological studies showed degeneration of the inner retina, more pronounced in the superior and inferior quadrant of the $\mathrm{ON}(2,70-75)$. In 2011, Koronyo-Hamaoui and colleagues documented for the first time extracerebral $\mathrm{A} \beta$ deposits in postmortem human retinas of $\mathrm{AD}$ patients and ex vivo in APPSWE/PS1 $\triangle \mathrm{E} 9$ transgenic mice after curcumin administration (15). In recent years, other histological studies of human retina confirmed the occurrence of extracellular plaques and intracellular $\mathrm{A} \beta$ deposits in the inner retinal layers involving mainly the superior hemiretina $(2,16,76,77)$. La Morgia and colleagues demonstrated that mRGCs, a subgroup of RGCs intrinsically photosensitive, are selectively affected by the amyloid pathology in AD. Remarkably, the loss of these cells 
occurred even with a normal RGC count, pointing to a specific AD pathology affecting mRGCs (2).

With the advent, in the last 15 years, of OCT, a non-invasive optical imaging technique of the retina and $\mathrm{ONH}$, many studies investigated the occurrence of $\mathrm{ON}$ pathology in $\mathrm{AD}$ and five comprehensive meta-analyses summarized the results provided by these OCT studies (3, 4, 78-80) (Table 2).

In 2017 , the most recent meta-analysis by den Haan and colleagues described the results on the average peripapillary RNFL in 24 studies including $887 \mathrm{AD}$ patients and 864 controls, and the 4 peripapillary RNFL quadrants in 20 studies. The RNFL thickness was thinner in $\mathrm{AD}$ compared with controls [standardized mean difference (SMD) -0.98], corresponding to an absolute reduction of about $10 \mu \mathrm{m}$. RNFL thinning was more pronounced in the superior and inferior peripapillary quadrants and was age-related (Table 2) (3). The same meta-analysis reported also data about mild cognitive impairment (MCI) patients (322 AD patients, 216 MCI patients, and 367 healthy controls), and RNFL thickness of MCI patients resulted intermediate between $\mathrm{AD}$ patients and healthy controls with a SMD of -0.71 compared with controls.

Furthermore, seven studies reported that total macular thickness is significantly reduced in $\mathrm{AD}$ retinas compared with controls with the largest effect on the outer macular ring [according to standard macular measures from the Early Treatment Diabetic Retinopathy Study (ETDRS)] (81). Moreover, the meta-regression by den Haan showed that OCT type, mini-mental state examination score, glaucoma exclusion score, and age were not associated with the SMD in the AD group compared with controls.

Overall, it must be emphasized that the results of OCT studies in $\mathrm{AD}$ are quite heterogeneous, due to the relatively small sample sizes and the different methods used for the data analysis. Moreover, not all the studies examined reported a thinning of the RNFL in AD patients (82). The main results of OCT studies in AD are summarized in Table 2 (82-105). Notwithstanding the technical limitations and some contrasting results, a specific pattern of axonal loss clearly emerged in the $\mathrm{ON}$ of $\mathrm{AD}$ patients, closely resembling the pattern of RGC loss described in glaucoma, i.e., the RNFL atrophy in the superior and inferior quadrants (18).

The relative sparing of the RNFL in the temporal quadrant and the predominant involvement of the superior and inferior RNFL quadrants (e.g., SDM for AD vs controls in temporal sector was -0.42 vs -0.99 in superior sector) indicate a preferential contribution of parasol RGCs projecting to the magnocellular pathway (M-cells), which are mainly located in the extra-macular retina and are not specifically contributing to visual acuity $(16,24)$. In this context, it should be mentioned that some authors suggested that RNFL thinning in the superior and inferior quadrants might be justified by the fact that more neurons physiologically are located in these quadrants where therefore neurodegeneration is more apparent (equal percentage corresponds to a greater absolute reduction in thickness) (3). However, this pattern remains clearly distinguishable from that described in PD, where a predominant loss of the P-cells is reported (57). Furthermore, recent histological findings in postmortem $\mathrm{AD}$ retinal specimens reported that the axonal loss predominantly affected the larger fibers in the superior quadrants, and, to a lesser extent, the nasal and inferior quadrants, whereas the temporal quadrants, were largely spared
TABLE 2 | OCT results in AD.

\begin{tabular}{|c|c|c|c|c|c|}
\hline & \multirow[t]{2}{*}{ OCT } & \multicolumn{3}{|c|}{ No. of patients } & \multirow[t]{2}{*}{ Results } \\
\hline & & AD & $\mathrm{MCl}$ & $\mathrm{HC}$ & \\
\hline $\begin{array}{l}\text { Pillai } \\
\text { et al. (82) }\end{array}$ & $\begin{array}{l}\text { Cirrus } 4000 \\
\text { HD }\end{array}$ & 21 & 20 & 34 & No significant differences \\
\hline $\begin{array}{l}\text { La Morgia } \\
\text { et al. ( } 2)\end{array}$ & Stratus OCT & 21 & & 74 & $\downarrow$ avg; sup RNFL thickness \\
\hline $\begin{array}{l}\text { Salobrar- } \\
\text { Garcia } \\
\text { et al. (83) }\end{array}$ & $\begin{array}{l}\text { OCT1000 } \\
\text { Topcon }\end{array}$ & 23 & & 28 & No significant differences \\
\hline $\begin{array}{l}\text { Eraslan } \\
\text { et al. (84) }\end{array}$ & RTVue-100 & 18 & & 20 & $\begin{array}{l}\downarrow \text { RNFL thickness and } \\
\text { macular GCC thickness }\end{array}$ \\
\hline $\begin{array}{l}\text { Güneş } \\
\text { et al. (85) }\end{array}$ & $\begin{array}{l}\text { OPKO/OTI } \\
\text { SD-OCT }\end{array}$ & 20 & & 20 & $\downarrow$ avg RNFL thickness \\
\hline $\begin{array}{l}\text { Liu } \\
\text { et al. (86) }\end{array}$ & Stratus OCT & 67 & 26 & 39 & $\downarrow$ avg; sup RNFL thickness \\
\hline $\begin{array}{l}\text { Oktem } \\
\text { et al. (87) }\end{array}$ & $\begin{array}{l}\text { Cirrus } \\
\text { HDOCT }\end{array}$ & 35 & 35 & 35 & $\downarrow$ avg RNFL thickness \\
\hline $\begin{array}{l}\text { Cheung } \\
\text { et al. (88) }\end{array}$ & $\begin{array}{l}\text { Cirrus } \\
\text { HDOCT }\end{array}$ & 100 & 41 & 123 & $\begin{array}{l}\downarrow \text { GC-IPL thickness in all } \\
\text { macular sectors } \\
\downarrow \text { Superior RNFL thickness }\end{array}$ \\
\hline $\begin{array}{l}\text { Gao } \\
\text { et al. (89) }\end{array}$ & $\begin{array}{l}\text { Cirrus } \\
\text { HDOCT }\end{array}$ & 25 & 26 & 21 & $\begin{array}{l}\downarrow \text { avg; sup RNFL thickness } \\
\downarrow \text { Macular volume in AD } \\
\text { and } \mathrm{MCl}\end{array}$ \\
\hline $\begin{array}{l}\text { Bambo } \\
\text { et al. (90) }\end{array}$ & $\begin{array}{l}\text { Cirrus } \\
\text { HDOCT }\end{array}$ & 56 & & 56 & $\downarrow$ avg RNFL thickness \\
\hline $\begin{array}{l}\text { Larrosa } \\
\text { et al. (91) }\end{array}$ & $\begin{array}{l}\text { Cirrus } \\
\text { HDOCT }\end{array}$ & 151 & & 61 & $\begin{array}{l}\downarrow \text { avg; sup and inf RNFL } \\
\text { thickness }\end{array}$ \\
\hline $\begin{array}{l}\text { Ascaso } \\
\text { et al. (92) }\end{array}$ & Stratus OCT & 18 & 21 & 41 & $\begin{array}{l}\downarrow \text { avg RNFL thickness } \\
\downarrow \text { Macular volume in } \mathrm{MCl} \\
\text { vs HC }\end{array}$ \\
\hline $\begin{array}{l}\text { Polo } \\
\text { et al. (93) }\end{array}$ & $\begin{array}{l}\text { Cirrus } \\
\text { HDOCT } \\
\text { Heidelberg } \\
\text { Spectralis }\end{array}$ & 70 & & 70 & $\begin{array}{l}\downarrow \text { avg; sup and inf RNFL } \\
\text { thickness }\end{array}$ \\
\hline $\begin{array}{l}\text { Gharbiya } \\
\text { et al. (94) }\end{array}$ & $\begin{array}{l}\text { Heidelberg } \\
\text { Spectralis }\end{array}$ & 21 & & 21 & $\begin{array}{l}\text { No differences in RNFL } \\
\text { thickness } \\
\downarrow \text { Choroidal thickness }\end{array}$ \\
\hline $\begin{array}{l}\text { Kromer } \\
\text { et al. (95) }\end{array}$ & $\begin{array}{l}\text { Heidelberg } \\
\text { Spectralis }\end{array}$ & 22 & & 22 & $\begin{array}{l}\downarrow \text { nas and sup sectors } \\
\text { RNFL thickness }\end{array}$ \\
\hline $\begin{array}{l}\text { Moreno- } \\
\text { Ramos } \\
\text { et al. (96) }\end{array}$ & $\begin{array}{l}\text { OCT1000 } \\
\text { Topcon }\end{array}$ & 10 & & 10 & $\downarrow$ avg RNFL thickness \\
\hline $\begin{array}{l}\text { Marziani } \\
\text { et al. (97) }\end{array}$ & $\begin{array}{l}\text { RTVue-100 } \\
\text { Heidelberg } \\
\text { Spectralis }\end{array}$ & 21 & & 21 & $\begin{array}{l}\downarrow \text { Macular RNFL and } \\
\text { macular RNFL }+ \text { GCL in all } \\
\text { sectors }\end{array}$ \\
\hline $\begin{array}{l}\text { Kirbas } \\
\text { et al. (98) }\end{array}$ & $\begin{array}{l}\text { OCT1000 } \\
\text { Topcon }\end{array}$ & 40 & & 40 & $\downarrow$ avg; sup RNFL thickness \\
\hline $\begin{array}{l}\text { Moschos } \\
\text { et al. (99) }\end{array}$ & Stratus OCT & 30 & & 30 & $\begin{array}{l}\downarrow \text { avg; sup and inf RNFL } \\
\text { thickness }\end{array}$ \\
\hline $\begin{array}{l}\text { Kesler } \\
\text { et al. (100) }\end{array}$ & Stratus OCT & 30 & 24 & 24 & $\begin{array}{l}\downarrow \text { avg; sup (AD) and inf } \\
\text { (MCl) RNFL thickness }\end{array}$ \\
\hline $\begin{array}{l}\text { Lu } \\
\text { et al. (101) }\end{array}$ & Stratus OCT & 22 & & 22 & $\begin{array}{l}\downarrow \text { avg; sup and inf RNFL } \\
\text { thickness }\end{array}$ \\
\hline $\begin{array}{l}\text { Paquet } \\
\text { et al. (102) }\end{array}$ & Stratus OCT & 26 & 23 & 15 & $\downarrow$ avg RNFL thickness \\
\hline
\end{tabular}

(Continued) 
TABLE 2 | Continued

\begin{tabular}{|c|c|c|c|c|c|}
\hline & \multirow[t]{2}{*}{ OCT } & \multicolumn{3}{|c|}{ No. of patients } & \multirow[t]{2}{*}{ Results } \\
\hline & & $A D$ & $\mathrm{MCl}$ & HC & \\
\hline $\begin{array}{l}\text { Berisha } \\
\text { et al. (103) }\end{array}$ & Stratus OCT & 9 & & 8 & $\begin{array}{l}\downarrow R N F L \text { thickness in the } \\
\text { superior quadrant }\end{array}$ \\
\hline $\begin{array}{l}\text { Iseri } \\
\text { et al. (104) }\end{array}$ & Stratus OCT & 14 & & 15 & $\begin{array}{l}\downarrow \text { avg RNFL thickness } \\
\downarrow \text { Macular volume }\end{array}$ \\
\hline $\begin{array}{l}\text { Parisi } \\
\text { et al. (105) }\end{array}$ & Stratus OCT & 17 & & 14 & $\downarrow$ avg RNFL thickness \\
\hline
\end{tabular}

$A D$, Alzheimer's disease; avg, average; temp, temporal; sup, superior; inf, inferior; nas, nasal; RNFL, retinal nerve fiber layer; GCC, ganglion cell complex; GCL, ganglion cell layer; OCT, optical coherence tomography; IPL, inner plexiform layer; $\mathrm{MCl}$, mild cognitive impairment.

$(2,16)$. The reasons why the M-cells are more vulnerable to AD pathology is still unknown but might be related to the different vulnerability of RGCs to amyloid deposition, which has been already demonstrated in mRGCs, characterized by a big soma and branched dendrites, similarly to M-cells (2).

\section{Multiple System Atrophy}

Multiple system atrophy is a neurodegenerative disorder typically defined by parkinsonian and cerebellar features and autonomic failure (106). The occurrence of RGC loss has been recently reported by different OCT studies (8).

Mendoza-Santiesteban and colleagues compared 24 MSA patients to $20 \mathrm{PD}$ and 35 controls demonstrating a significant RNFL and ganglion cell complex (GCL + IPL) thinning in the MSA patients compared with controls. Interestingly, in the MSA group the RNFL thinning was significant in the inferior quadrant relatively sparing the temporal region, thus clearly distinguishable from the PD cohort where a predominant temporal pattern was consistently found. The authors speculated that the different pattern of axonal loss could be due to different patterns of myelination by oligodendrocytes of M-cells axons (7), which might also explain the absence of visual complaints and normal visual acuity reported by MSA patients $(7,8)$. Similar results in terms of pattern of RNFL loss have been reported also by other studies (107-109).

\section{Glaucoma}

Elevated intraocular pressure (IOP) is the main risk factor for glaucoma, but even glaucomatous patients with IOP within normal limit will progress in loosing RGCs (110). The hypothesis that larger RGCs are preferentially affected in human, and experimental glaucoma has received remarkable credit since Quigley and colleagues formulated it in 1987 (18, 28, 111). This hypothesis was corroborated by postmortem examination of the human LGN of glaucoma patients where a selective neuronal loss in the layers receiving input from parasol cells was shown (112). Over the years, the selective damage of M-cells or S-cone pathway (113) has been debated with contrasting opinions (114-117).

Nonetheless, recent studies in experimental glaucoma demonstrated that RGCs undergo morphologic changes before cell death, which are represented by reduction of soma volume, axon size, and dendritic tree area. These changes are consistent with cell shrinkage as an explanation for the apparent survival of midget cells reported in earlier studies (118). Weber and colleagues $(119,120)$ found a reduction in thickness and complexity of the dendritic tree in primate glaucomatous retinas, highlighting that $\mathrm{M}$-cells and P-cells were involved to a similar extent (121). Moreover, psychophysical studies comparing responses of $\mathrm{M}$ and $\mathrm{P}$ pathways, found contrasting results, some supporting similar dysfunction for both pathways (122), whereas others suggested that visual functions such as contrast sensitivity and contrast gain signature, mediated by the $\mathrm{M}$ pathway, were reduced in glaucoma (123).

Even if the mechanisms underlying axonal damage in glaucoma are still not completely understood, the pattern of peripapillar and macular RNFL thinning is now well described by OCT studies.

Schuman and colleagues in 1995 (124) showed for the first time a thinning of the RNFL in glaucomatous eyes as compared with normal eyes, more evident in the inferior quadrant. In 2005, using Stratus OCT (time-domain OCT) Leung and colleagues noticed the greatest reductions in peripapillary RNFL thickness in glaucoma at the superotemporal (11 o' clock) and inferotemporal (7 o'clock) sectors. These changes are congruent with the distribution of the most commonly reported visual field defect in glaucoma (125). Subsequently, numerous OCT studies have confirmed the typical pattern of relative sparing of peripapillary RNFL in the temporal quadrant and the resulting greater diagnostic performance to distinguish normal eyes from eyes with early glaucoma by looking at the inferior (inferotemporal) and superior (superotemporal) RNFL quadrants (126). In more recent years, with the advent of spectral-domain OCT and its greater spatial resolution, it has been possible to measure with higher reliability the thickness of the RNFL and the retinal ganglion cell plus inner plexiform (RGC+) just in the macula (127). Hood and coauthors demonstrated a greater thinning of the macular RGC+ thickness in the inferior macula (superior visual field) in glaucoma patients (128), corresponding to the typical arcuate RGC damage associated with local peripapillar RNFL thinning in a confined region of the disc, which the authors named "the macular vulnerability zone” (about 7:00 o' clock). Furthermore, the authors reported that the temporal region of the disc, where axons come from the upper and nasal macula, showed a milder damage until late stages of the disease.

Overall, the pattern described by OCT studies in glaucoma clearly points to a predominant damage of the inferior and superior ON quadrants where M-cells are preferentially located, with a relative sparing of the temporal sector (P-cells), similar to what has been described in AD and MSA.

\section{Conclusions}

Optical coherence tomography is an extraordinary tool to assess anatomy in vivo, to describe subtle differences in the patterns of neurodegeneration and to provide possible mechanistic insights for ON damage in different human diseases.

Mechanisms of neurodegeneration may act at different levels of the RGC/ON system, which is composed by RGC dendritic tree, the soma, the axon in its unmyelinated intraretinal component and the transition through the lamina cribrosa at the $\mathrm{ONH}$, and the post-laminar myelinated component. Moreover, large 
and small RGCs and thicker and thinner axons display different conduction velocities, thus metabolic requirements and myelin sheath turnover. All these elements, and others that we know less, such as vascularization, support from glial cells and anatomical microenvironment come into play, possibly differentiating mechanistically the neurodegenerative pattern.

It must be also considered that a trans-synaptic degeneration may occur in some circumstances, such as in the specific case documented in AD where both the SCN and the mRGCs are affected by amyloid deposition supporting the hypothesis of a global involvement of the retino-hypothalamic tract $(2,129)$. Despite evidences are not conclusive it cannot be excluded that retinal degeneration in these disorders can be also contributed by trans-synaptic neurodegeneration.

Current evidences for PD suggest a number of possible co-occurring pathological events. Dopaminergic depletion may affect the connecting circuitry such as the amacrine cells, possibly leading to RGC de-afferentation and dendritic remodeling. However, mounting evidences highlight $\alpha$-synuclein deposition in PD retinas, and mitochondrial dysfunction, not surprisingly, may ultimately lead to a prevalent damage of the $\mathrm{P}$-cells. This is consistent with current OCT results pointing to a predominant "mitochondrial-like" pattern of ON degeneration. The $\alpha$-synuclein deposition in the retina, which might support a primary neurodegenerative process, parallels the recent findings of $\alpha$-synuclein deposition demonstrated in the skin nerves of PD patients (130).

In $\mathrm{AD}$, similar to $\mathrm{PD}$, there is deposition of an abnormally folded protein, i.e., $\beta$-amyloid, which, however, presents with a peculiar retinal topography involving preferentially the peripheral retina in the superior quadrant, as recently shown (16). At this regard, Koronyo and coauthors have recently demonstrated that amyloid plaques can be visualized in vivo in $\mathrm{AD}$ human eyes using oral curcumin, opening the possibility to use the eye as a reliable and easily accessible biomarker for this disease (16).

\section{REFERENCES}

1. Hinton DR, Sadun AA, Blanks JC, Miller CA. Optic-nerve degeneration in Alzheimer's disease. N Engl J Med (1986) 315:485-7. doi:10.1056/ NEJM198608213150804

2. La Morgia C, Ross-Cisneros FN, Koronyo Y, Hannibal J, Gallassi R, Cantalupo G, et al. Melanopsin retinal ganglion cell loss in Alzheimer disease. Ann Neurol (2016) 79:90-109. doi:10.1002/ana.24548

3. den Haan J, Verbraak FD, Visser PJ, Bouwman FH. Retinal thickness in Alzheimer's disease: a systematic review and meta-analysis. Alzheimers Dement (Amst) (2017) 6:162-70. doi:10.1016/j.dadm.2016.12.014

4. Coppola G, Di Renzo A, Ziccardi L, Martelli F, Fadda A, Manni G, et al. Optical coherence tomography in Alzheimer's disease: a meta-analysis. PLoS One (2015) 10:e0134750. doi:10.1371/journal.pone.0134750

5. Yu JG, Feng YF, Xiang Y, Huang JH, Savini G, Parisi V, et al. Retinal nerve fiber layer thickness changes in Parkinson disease: a meta-analysis. PLoS One (2014) 9:e85718. doi:10.1371/journal.pone.0085718

6. Andrade C, Beato J, Monteiro A, Costa A, Penas S, Guimarães J, et al. Spectral-domain optical coherence tomography as a potential biomarker in Huntington's disease. Mov Disord (2016) 31:377-83. doi:10.1002/mds.26486

7. Mendoza-Santiesteban CE, Palma JA, Martinez J, Norcliffe-Kaufmann L, Hedges TR III, Kaufmann H. Progressive retinal structure abnormalities in multiple system atrophy. Mov Disord (2015) 30:1944-53. doi:10.1002/ mds. 26360
Overall, in AD the OCT results, as well as the histological studies, point to a predominant affection of the M-cells, which somehow links AD to what is observed in glaucoma. This parallel may suggest that a relevant role is played by the $\mathrm{ONH}$ anatomy, where fibers turn $90^{\circ}$ to engage into the transition through the lamina cribrosa, where a still poorly understood mechanism hits the larger axons driving M-RGC loss. The dichotomy between the two opposite patterns of prevalent $\mathrm{P}$-cells vs $\mathrm{M}$-cells vulnerability is further reflected in other two neurodegenerative disorders, HD as opposed to MSA. Remarkably, MSA that is a synucleinopathy with parkinsonism displays an OCT pattern more similar to $\mathrm{AD}$, whereas $\mathrm{HD}$ is closer to PD. This latter link may be again supported by the common intrinsic mitochondrial dysfunction, whereas the link between MSA and AD in terms of retinal pathology remains puzzling and deserves further investigations.

Overall, OCT proves to be a powerful tool to assess anatomically neurodegeneration in vivo providing, once solidly validated by complementary postmortem histological studies, a great potential in all neurodegenerative disorders for monitoring natural history and ultimately possibly validate neuroprotective therapeutic strategies by proving their efficacy.

\section{AUTHOR CONTRIBUTIONS}

CLM and MC were responsible for conception, design, drafting, and revision of the manuscript. LV was responsible for drafting and revision of the manuscript. VC was responsible for conception and revision of the manuscript.

\section{FUNDING}

This work was supported by the Ministry of Health Young Researcher project (GR-2013-02358026) (to CLM) and by the Italian Ministries of Health and of Research and the Gino Galletti Foundation (to VC).

8. Mendoza-Santiesteban CE, Gabilondo I, Palma JA, Norcliffe-Kaufmann $\mathrm{L}$, Kaufmann $\mathrm{H}$. The retina in multiple system atrophy: systematic review and meta-analysis. Front Neurol (2017) 8:206. doi:10.3389/ fneur.2017.00206

9. La Morgia C, Carbonelli M. Chapter 8: Friedreich's ataxia and more: optical coherence tomography findings in rare neurological syndromes. in OCT in Central Nervous System Diseases: The Eye as a Window to the Brain. Springer International Publishing. (2016). p. 143-66.

10. Klebe S, Depienne C, Gerber S, Challe G, Anheim M, Charles P, et al. Spastic paraplegia gene 7 in patients with spasticity and/or optic neuropathy. Brain (2012) 135(Pt 10):2980-93. doi:10.1093/brain/aws240

11. Carelli V, Ross-Cisneros FN, Sadun AA. Mitochondrial dysfunction as a cause of optic neuropathies. Prog Retin Eye Res (2004) 23:53-89. doi:10.1016/j. preteyeres.2003.10.003

12. Lin WJ, Kuang HY. Oxidative stress induces autophagy in response to multiple noxious stimuli in retinal ganglion cells. Autophagy (2014) 10(10):1692-701. doi:10.4161/auto.36076

13. Bodis-Wollner I, Kozlowski PB, Glazman S, Miri S. $\alpha$-synuclein in the inner retina in Parkinson disease. Ann Neurol (2014) 75:964-6. doi:10.1002/ ana. 24182

14. Beach TG, Carew J, Serrano G, Adler CH, Shill HA, Sue LI, et al. Phosphorylated $\alpha$-synuclein-immunoreactive retinal neuronal elements in Parkinson's disease subjects. Neurosci Lett (2014) 571:34-8. doi:10.1016/j. neulet.2014.04.027 
15. Koronyo-Hamaoui M, Koronyo Y, Ljubimov AV, Miller CA, Ko MK, Black KL, et al. Identification of amyloid plaques in retinas from Alzheimer's patients and noninvasive in vivo optical imaging of retinal plaques in a mouse model. Neuroimage (2011) 54(Suppl 1):S204-17. doi:10.1016/j. neuroimage.2010.06.020

16. Koronyo Y, Biggs D, Barron E, Boyer DS, Pearlman JA, Au WJ, et al. Retinal amyloid pathology and proof-of-concept imaging trial in Alzheimer's disease. JCI Insight (2017) 2(16):93621. doi:10.1172/jci.insight.93621

17. La Morgia C, Ross-Cisneros FN, Sadun AA, Carelli V. Retinal ganglion cells and circadian rhythms in Alzheimer's disease, Parkinson's disease, and beyond. Front Neurol (2017) 8:162. doi:10.3389/fneur.2017.00162

18. Quigley HA, Dunkelberger GR, Green WR. Chronic human glaucoma causing selectively greater loss of large optic nerve fibers. Ophthalmology (1988) 95:357-63. doi:10.1016/S0161-6420(88)33176-3

19. Yu-Wai-Man P, Griffiths PG, Chinnery PF. Mitochondrial optic neuropathies disease mechanisms and therapeutic strategies. Prog Retin Eye Res (2011) 30(2):81-114. doi:10.1016/j.preteyeres.2010.11.002

20. Mead B, Tomarev S. Evaluating retinal ganglion cell loss and dysfunction. Exp Eye Res (2016) 151:96-106. doi:10.1016/j.exer.2016.08.006

21. Sanes JR, Masland RH. The types of retinal ganglion cells: current status and implications for neuronal classification. Annu Rev Neurosci (2015) 38:221-46. doi:10.1146/annurev-neuro-071714-034120

22. Polyak SL. The Retina. Illinois: The University of Chicago Press (1941).

23. Kolb H, DeKorver L. Midget ganglion cells of the parafovea of the human retina: a study by electron microscopy and serial section reconstructions. J Comp Neurol (1991) 303:617-36. doi:10.1002/cne.903030408

24. Kolb H, Fernandez E, Nelson R, editors. Webvision: The Organization of the Retina and Visual System. Salt Lake City, UT: University of Utah Health Sciences Center (1995). Available from http://www.ncbi.nlm.nih.gov/books/ NBK11530/

25. Silveira LC, Saito CA, Lee BB, Kremers J, da Silva Filho M, Kilavik BE, et al. Morphology and physiology of primate M- and P-cells. Prog Brain Res (2004) 144:21-46. doi:10.1016/S0079-6123(03)14402-0

26. Perge JA, Niven JE, Mugnaini E, Balasubtamanian V, Sterling P. Why do axon differ in caliber. J Neurosci (2012) 32(2):626-38. doi:10.1523/ JNEUROSCI.4254-11.2012

27. Hogan MJ, Alvarado JA, Weddell JE. Histology of the Human Eye: An Atlas and Textbook. Philadelphia: Saunders (1971).

28. Hoyt WF, Tudor RC. The course of parapapillary temporal retinal axons through the anterior optic nerve. A Nauta degeneration study in the primate. Arch Ophthalmol (1963) 69:503-7. doi:10.1001/archopht.1963.00960040509014

29. Postuma RB, Berg D, Stern M, Poewe W, Olanow CW, Oertel W, et al. MDS clinical diagnostic criteria for Parkinson's disease. Mov Disord (2015) 30(12):1591-601. doi:10.1002/mds.26424

30. Lee A, Gilbert RM. Epidemiology of Parkinson disease. Neurol Clin (2016) 34:955-65. doi:10.1016/j.ncl.2016.06.012

31. Archibald NK, Clarke MP, Mosimann UP, Burn DJ. The retina in Parkinson's disease. Brain (2009) 132:1128-45. doi:10.1093/brain/awp068

32. Weil RS, Schrag AE, Warren JD, Crutch SJ, Lees AJ, Morris HR. Visual dysfunction in Parkinson's disease. Brain (2016) 139:2827-43. doi:10.1093/ brain/aww175

33. Inzelberg R, Ramirez JA, Nisipeanu P, Ophir A. Retinal nerve fiber layer thinning in Parkinson disease. Vision Res (2004) 44(24):2793-7. doi:10.1016/j. visres.2004.06.009

34. Yavas GF, Yilmaz O, Küsbeci T, Oztürk F. The effect of levodopa and dopamine agonists on optic nerve head in Parkinson disease. Eur J Ophthalmol (2007) 17(5):812-6.

35. Altintaş O, Işeri P, Ozkan B, Cağlar Y. Correlation between retinal morphological and functional findings and clinical severity in Parkinson's disease. Doc Ophthalmol (2008) 116(2):137-46. doi:10.1007/s10633-0079091-8

36. Hajee ME, March WF, Lazzaro DR, Wolintz AH, Shrier EM, Glazman S, et al. Inner retinal layer thinning in Parkinson disease. Arch Ophthalmol (2009) 127(6):737-41. doi:10.1001/archophthalmol.2009.106

37. Cubo E, Tedejo RP, Rodriguez Mendez V, López Peña MJ, Trejo Gabriel Y, Galán JM. Retina thickness in Parkinson's disease and essential tremor. Mov Disord (2010) 25(14):2461-2. doi:10.1002/mds.23215

38. Moschos MM, Tagaris G, Markopoulos I, Margetis I, Tsapakis S, Kanakis M, et al. Morphologic changes and functional retinal impairment in patients with Parkinson disease without visual loss. Eur J Ophthalmol (2011) 21(1): 24-9. doi:10.5301/EJO.2010.1318

39. Garcia-Martin E, Satue M, Fuertes I, Otin S, Alarcia R, Herrero R. Ability and reproducibility of Fourier-domain optical coherence tomography to detect retinal nerve fiber layer atrophy in Parkinson's disease. Ophthalmology (2012) 119(10):2161-7. doi:10.1016/j.ophtha.2012.05.003

40. Rohani M, Langroodi AS, Ghourchian S, Falavarjani KG, SoUdi R, Shahidi G. Retinal nerve changes in patients with tremor dominant and akinetic rigid Parkinson's disease. Neurol Sci (2013) 34(5):689-93. doi:10.1007/s10072012-1125-7

41. Kirbas S, Turkyilmaz K, Tufekci A, Durmus M. Retinal nerve fiber layer thickness in Parkinson disease. J Neuroophthalmol (2013) 33(1):62-5. doi:10.1097/WNO.0b013e3182701745

42. La Morgia C, Barboni P, Rizzo G, Carbonelli M, Savini G, Scaglione C, et al. Loss of temporal retinal nerve fibers in Parkinson disease: a mitochondrial pattern? Eur J Neurol (2013) 20(1):198-201. doi:10.1111/j.1468-1331.2012.03701.x

43. Satue M, Garcia-Martin E, Fuertes I, Otin S, Alarcia R, Herrero R. Use of Fourier-domain OCT to detect retinal nerve fiber layer degeneration in Parkinson's disease patients. Eye (Lond) (2013) 27(4):507-14. doi:10.1038/ eye.2013.4

44. Adam CR, Shrier E, Ding Y, Glazman S, Bodis-Wollner I. Correlation of inner retinal thickness evaluated by spectral-domain optical coherence tomography and contrast sensitivity in Parkinson disease. J Neuroophthalmol (2013) 33(2):137-42. doi:10.1097/WNO.0b013e31828c4ela

45. Sen A, Tugcu B, Coskun C, Ekinci C, Nacaroglu SA. Effects of levodopa on retina in Parkinson disease. Eur JOphthalmol (2014) 24(1):114-9. doi:10.5301/ejo.5000338

46. Cubo E, López Peña MJ, Diez-Feijo Varela E, Pérez Gil O, Garcia Gutierrez P, et al. Lack of association of morphologic and functional retinal changes with motor and non-motor symptoms severity in Parkinson's disease. J Neural Transm (Vienna) (2014) 121(2):139-45. doi:10.1007/s00702-013-1093-y

47. Satue M, Seral M, Otin S, Alarcia R, Herrero R, Bambo MP, et al. Retinal thinning and correlation with functional disability in patients with Parkinson's disease. Br JOphthalmol (2014) 98(3):350-5. doi:10.1136/ bjophthalmol-2013-304152

48. Garcia-MartinE, Rodriguez-MenaD, SatueM,AlmarceguiC,DolzI, Alarcia R, et al. Electrophysiology and optical coherence tomography to evaluate Parkinson disease severity. Invest Ophthalmol Vis Sci (2014) 55(2):696-705. doi:10.1167/iovs.13-13062

49. Garcia-Martin E, Larrosa JM, Polo V, Satue M, Marques ML, Alarcia R. Distribution of retinal layer atrophy in patients with Parkinson disease and association with disease severity and duration. Am JOphthalmol (2014) 157(2):470-8.e2. doi:10.1016/j.ajo.2013.09.028

50. Jiménez B, Ascaso FJ, Cristóbal JA, López del Val J. Development of a prediction formula of Parkinson disease severity by optical coherence tomography. Mov Disord (2014) 29(1):68-74. doi:10.1002/mds.25747

51. Bayhan HA, Aslan Bayhan S, Tanı N, Gürdal C. The association of spectral-domain optical coherence tomography determined ganglion cell complex parameters and disease severity in Parkinson's disease. Curr Eye Res (2014) 39(11):1117-22. doi:10.3109/02713683.2014.894080

52. Sari ES, Koc R, Yazici A, Sahin G, Ermis SS. Ganglion cell-inner plexiform layer thickness in patients with Parkinson disease and association with disease severity and duration. J Neuroophthalmol (2015) 35(2):117-21. doi:10.1097/WNO.0000000000000203

53. Kaur M, Saxena R, Singh D, Behari M, Sharma P, Menon V. Correlation between structural and functional retinal changes in Parkinson disease. J Neuroophthalmol (2015) 35(3):254-8. doi:10.1097/WNO.0000000000000240

54. Stemplewitz B, Keserü M, Bittersohl D, Buhmann C, Skevas C, Richard G, et al. Scanning laser polarimetry and spectral domain optical coherence tomography for the detection of retinal changes in Parkinson's disease. Acta Ophthalmol (2015) 93(8):e672-7. doi:10.1111/aos.12764

55. Eraslan M, Balci SY, Cerman E, Temel A, Suer D, Elmaci NT. Comparison of optical coherence tomography findings in patients with primary openangle glaucoma and Parkinson disease. J Glaucoma (2016) 25(7):e639-46. doi:10.1097/IJG.0000000000000239

56. Pilat A, McLean RJ, Proudlock FA, Maconachie GD, Sheth V, Rajabally YA, et al. In vivo morphology of the optic nerve and retina in patients with Parkinson's disease. Invest Ophthalmol Vis Sci (2016) 57(10):4420-7. doi:10.1167/iovs.16-20020 
57. Bodis-Wollner I, Miri S, Glazman S. Venturing into the no-man's land of the retina in Parkinson's disease. Mov Disord (2014) 29(1):15-22. doi:10.1002/ mds. 25741

58. Pan BX, Ross-Cisneros FN, Carelli V, Rue KS, Salomao SR, Moraes-Filho MN, et al. Mathematically modeling the involvement of axons in Leber's hereditary optic neuropathy. Invest Ophthalmol Vis Sci (2012) 53(12):7608-17. doi:10.1167/iovs.12-10452

59. Giannoccaro MP, La Morgia C, Rizzo G, Carelli V. Mitochondrial DNA and primary mitochondrial dysfunction in Parkinson's disease. Mov Disord (2017) 32(3):346-63. doi:10.1002/mds.26966

60. Spund B, Ding Y, Liu T, Selesnick I, Glazman S, Shrier EM, et al. Remodeling of the fovea in Parkinson disease. JNeural Transm (Vienna) (2013) 120(5):745-53. doi:10.1007/s00702-012-0909-5

61. Shrier EM, Adam CR, Spund B, Glazman S, Bodis-Wollner I. Interocular asymmetry of foveal thickness in Parkinson disease. JOphthalmol (2012)2012:728457. doi:10.1155/2012/728457

62. McColgan P, Tabrizi SJ. Huntington's disease: a clinical review. Eur J Neurol (2017). doi:10.1111/ene.13413

63. Morton AJ. Circadian and sleep disorder in Huntington's disease. Exp Neurol (2013) 243:34-44. doi:10.1016/j.expneurol.2012.10.014

64. Kersten HM, Danesh-Meyer HV, Kilfoyle DH, Roxburgh RH. Optical coherence tomography findings in Huntington's disease: a potential biomarker of disease progression. J Neurol (2015) 262:2457-65. doi:10.1007/ s00415-015-7869-2

65. Guedes-Dias P, Pinho BR, Soares TR, de Proença J, Duchen MR, Oliveira JM. Mitochondrial dynamics and quality control in Huntington's disease. Neurobiol Dis (2016) 90:51-7. doi:10.1016/j.nbd.2015.09.008

66. Oliveira JM. Nature and cause of mitochondrial dysfunction in Huntington's disease: focusing on huntingtin and the striatum. JNeurochem (2010) 114:1-12. doi:10.1111/j.1471-4159.2010.06741.x

67. McKhann G, Drachman D, Folstein M, Katzman R, Price D, Stadlan EM. Clinical diagnosis of Alzheimer's disease: report of the NINCDS-ADRDA Work Group under the auspices of Department of Health and Human Services Task Force on Alzheimer's Disease. Neurology (1984) 34(7):939-44. doi:10.1212/WNL.34.7.939

68. Cronin-Golomb A, Corkin S, Rizzo JF, Cohen J, Growdon JH, Banks KS. Visual dysfunction in Alzheimer's disease: relation to normal aging. Ann Neurol (1991) 29(1):41-52. doi:10.1002/ana.410290110

69. RizzoJFIII,Cronin-Golomb A, GrowdonJH,CorkinS, RosenTJ,SandbergMA, et al. Retinocalcarine function in Alzheimer's disease. A clinical and electrophysiological study. Arch Neurol (1992) 49(1):93-101. doi:10.1001/ archneur.1992.00530250097023

70. Blanks JC, Hinton DR, Sadun AA, Miller CA. Retinal ganglion cell degeneration in Alzheimer's disease. Brain Res (1989) 501:364-72. doi:10.1016/ 0006-8993(89)90653-7

71. Blanks JC, Torigoe Y, Hinton DR, Blanks RH. Retinal degeneration in the macula of patients with Alzheimer's disease. Ann N Y Acad Sci (1991) 640:44-6. doi:10.1111/j.1749-6632.1991.tb00188.x

72. Sadun AA, Bassi CJ. Optic nerve damage in Alzheimer's disease. Ophthalmology (1990) 97:9-17. doi:10.1016/S0161-6420(90)32621-0

73. Blanks JC, Schmidt SY, Torigoe Y, Porrello KV, Hinton DR, Blanks RH. Retinal pathology in Alzheimer's disease. II. Regional neuron loss and glial changes in GCL. Neurobiol Aging (1996) 17:385-95. doi:10.1016/0197-4580(96)00009-7

74. Blanks JC, Torigoe Y, Hinton DR, Blanks RH. Retinal pathology in Alzheimer's disease. I. Ganglion cell loss in foveal/parafoveal retina. Neurobiol Aging (1996) 17:377-84. doi:10.1016/0197-4580(96)00010-3

75. Curcio CA, Drucker DN. Retinal ganglion cells in Alzheimer's disease and aging. Ann Neurol (1993) 33:248-57. doi:10.1002/ana.410330305

76. Alexandrov PN, Pogue A, Bhattacharjee S, Lukiw WJ. Retinal amyloid peptides and complement factor $\mathrm{H}$ in transgenic models of Alzheimer's disease. Neuroreport (2011) 22:623-7. doi:10.1097/WNR.0b013e3283497334

77. Hart NJ, Koronyo Y, Black KL, Koronyo-Hamaoui M. Ocular indicators of Alzheimer's: exploring disease in the retina. Acta Neuropathol (2016) 132:767-87. doi:10.1007/s00401-016-1613-6

78. Thomson KL, Yeo JM, Waddell B, Cameron JR, Pal S. A systematic review and meta-analysis of retinal nerve fiber layer change in dementia, using optical coherence tomography. Alzheimers Dement (Amst) (2015) 1(2):136-43. doi:10.1016/j.dadm.2015.03.001
79. Wang M, Zhu Y, Shi Z, Li C, Shen Y. Meta-analysis of the relationship of peripheral retinal nerve fiber layer thickness to Alzheimer's disease and mild cognitive impairment. Shanghai Arch Psychiatry (2015) 27(5):263-79. doi:10.11919/j.issn.1002-0829.215100

80. Cunha LP, Almeida AL, Costa-Cunha LV, Costa CF, Monteiro ML. The role of optical coherence tomography in Alzheimer's disease. Int J Retina Vitreous (2016) 2:24. doi:10.1186/s40942-016-0049-4

81. Photocoagulation for diabetic macular edema. Early treatment diabetic re-tinopathy study report number 1. Early Treatment Diabetic Retinopathy Study Research Group. Arch Ophthalmol (1985) 103:1796-806. doi:10.1001/ archopht.1985.01050120030015

82. Pillai JA, Bermel R, Bonner-Jackson A, Rae-Grant A, Fernandez H, Bena J, et al. Retinal nerve fiber layer thinning in Alzheimer's disease: a case-control study in comparison to normal aging, Parkinson's disease, and nonAlzheimer's dementia. Am J Alzheimers Dis Other Demen (2016) 31:430-6. doi: $10.1177 / 1533317515628053$

83. Salobrar-Garcia E, Hoyas I, Leal M, de Hoz R, Rojas B, Ramirez AI, et al. Analysis of retinal peripapillary segmentation in early Alzheimer's disease patients. Biomed Res Int (2015) 2015:636548. doi:10.1155/2015/636548

84. Eraslan M, Çerman E, Çekiç O, Balci S, Dericioğlu V, Sahin Ö, et al. Neurodegeneration in ocular and central nervous systems: optical coherence tomography study in normal-tension glaucoma and Alzheimer disease. Turk J Med Sci (2015) 45(5):1106-14. doi:10.3906/sag-1406-145

85. Güneş A, Demirci S, Tök L, Tök Ö, Demirci S. Evaluation of retinal nerve fiber layer thickness in Alzheimer disease using spectral-domain optical coherence tomography. Turk J Med Sci (2015) 45(5):1094-7. doi:10.1167/ iovs.13-12046

86. Liu D, Zhang L, Li Z, Zhang X, Wu Y, Yang H, et al. Thinner changes of the retinal nerve fiber layer in patients with mild cognitive impairment and Alzheimer's disease. BMC Neurol (2015) 15:14. doi:10.1186/s12883-015-0268-6

87. Oktem EO, Derle E, Kibaroglu S, Oktem C, Akkoyun I, Can U. The relationship between the degree of cognitive impairment and retinal nerve fiber layer thickness. Neurol Sci (2015) 36:1141-6. doi:10.1007/s10072-014-2055-3

88. Cheung CY, Ong YT, Hilal S, Ikram MK, Low S, Ong YL, et al. Retinal ganglion cell analysis using high-definition optical coherence tomography in patients with mild cognitive impairment and Alzheimer's disease. J Alzheimers Dis (2015) 45:45-56. doi:10.3233/JAD-141659

89. Gao L, Liu Y, Li X, Bai Q, Liu P. Abnormal retinal nerve fiber layer thickness and macula lutea in patients with mild cognitive impairment and Alzheimer's disease. Arch Gerontol Geriatr (2015) 60:162-7. doi:10.1016/j. archger.2014.10.011

90. Bambo MP, Garcia-Martin E, Gutierrez-Ruiz F, Pinilla J, PerezOlivan S, Larrosa JM, et al. Analysis of optic disc color changes in Alzheimer's disease: a potential new biomarker. Clin Neurol Neurosurg (2015) 132:68-73. doi:10.1016/j.clineuro.2015.02.016

91. Larrosa JM, Garcia-Martin E, Bambo MP, Pinilla J, Polo V, Otin S, et al. Potential new diagnostic tool for Alzheimer's disease using a linear discriminant function for Fourier domain optical coherence tomography. Invest Ophthalmol Vis Sci (2014) 55:3043-51. doi:10.1167/iovs.13-13629

92. Ascaso FJ, Cruz N, Modrego PJ, Lopez-Anton R, Santabarbara J, Pascual LF, et al. Retinal alterations in mild cognitive impairment and Alzheimer's disease: an optical coherence tomography study. J Neurol (2014) 261:1522-30. doi:10.1007/s00415-014-7374-z

93. Polo V, Garcia-Martin E, Bambo MP, Pinilla J, Larrosa JM, Satue M, et al. Reliability and validity of Cirrus and Spectralis optical coherence tomography for detecting retinal atrophy in Alzheimer's disease. Eye (Lond) (2014) 28:680-90. doi:10.1038/eye.2014.51

94. Gharbiya M, Trebbastoni A, Parisi F, Manganiello S, Cruciani F, D’Antonio F, et al. Choroidal thinning as a new finding in Alzheimer's disease: evidence from enhanced depth imaging spectral domain optical coherence tomography. J Alzheimers Dis (2014) 40:907-17. doi:10.3233/JAD-132039

95. Kromer R, Serbecic N, Hausner L, Froelich L, Aboul-Enein F, Beutelspacher SC. Detection of retinal nerve fiber layer defects in Alzheimer's disease using SD-OCT. Front Psychiatry (2014) 5:22. doi:10.3389/fpsyt.2014.00022

96. Moreno-Ramos T, Benito-León J, Villarejo A, Bermejo-Pareja F. Retinal nerve fiber layer thinning in dementia associated with Parkinson's disease, dementia with Lewy bodies, and Alzheimer's disease. J Alzheimers Dis (2013) 34(3):659-64. doi:10.3233/JAD-121975 
97. Marziani E, Pomati S, Ramolfo P, Cigada M, Giani A, Mariani C, et al. Evaluation of retinal nerve fiber layer and ganglion cell layer thickness in Alzheimer's disease using spectral-domain optical coherence tomography. Invest Ophthalmol Vis Sci (2013) 54:5953-8. doi:10.1167/iovs.13-12046

98. Kirbas S, Turkyilmaz K, Anlar O, Tufekci A, Durmus M. Retinal nerve fiber layer thickness in patients with Alzheimer disease. J Neuroophthalmol (2013) 33:58-61. doi:10.1097/WNO.0b013e318267fd5f

99. Moschos MM, Markopoulos I, Chatziralli I, Rouvas A, Papageorgiou SG, Ladas I, et al. Structural and functional impairment of the retina and optic nerve in Alzheimer's disease. Curr Alzheimer Res (2012) 9:782-8. doi:10.2174/156720512802455340

100. Kesler A, Vakhapova V, Korczyn AD, Naftaliev E, Neudorfer M. Retinal thickness in patients with mild cognitive impairment and Alzheimer's disease. Clin Neurol Neurosurg (2011) 113:523-6. doi:10.1016/j.clineuro.2011.02.014

101. Lu Y, Li Z, Zhang X, Ming B, Jia J, Wang R, et al. Retinal nerve fiber layer structure abnormalities in early Alzheimer's disease: evidence in optical coherence tomography. Neurosci Lett (2010) 480:69-72. doi:10.1016/j. neulet.2010.06.006

102. Paquet C, Boissonnot M, Roger F, Dighiero P, Gil R, Hugon J, et al. Abnormal retinal thickness in patients with mild cognitive impairment and Alzheimer's disease. Neurosci Lett (2007) 420:97-9. doi:10.1016/j.neulet.2007.02.090

103. Berisha F, Feke GT, Trempe CL, McMeel JW, Schepens CL. Retinal abnormalities in early Alzheimer's disease. Invest Ophthalmol Vis Sci (2007) 48:2285-9. doi:10.1167/iovs.06-1029

104. Iseri PK, Altinas O, Tokay T, Yuksel N. Relationship between cognitive impairment and retinal morphological and visual functional abnormalities in Alzheimer disease. J Neuroophthalmol (2006) 26:18-24. doi:10.1097/01. wno.0000204645.56873.26

105. Parisi V, Restuccia R, Fattapposta F, Mina C, Bucci MG, Pierelli F. Morphological and functional retinal impairment in Alzheimer's disease patients. Clin Neurophysiol (2001) 112:1860-7. doi:10.1016/S1388-2457(01)00620-4

106. Gilman S, Wenning GK, Low PA, Brooks DJ, Mathias CJ, Trojanowski JQ, et al. Second consensus statement on the diagnosis of multiple system atrophy. Neurology (2008) 71(9):670-6. doi:10.1212/01.wnl.0000324625.00404.15

107. Schneider M, Müller HP, Lauda F, Tumani H, Ludolph AC, Kassubek J, et al. Retinal single-layer analysis in Parkinsonian syndromes: an optical coherence tomography study. J Neural Transm (Vienna) (2014) 121(1):41-7. doi:10.1007/s00702-013-1072-3

108. Albrecht P, Müller AK, Südmeyer M, Ferrea S, Ringelstein M, Cohn E, et al. Optical coherence tomography in Parkinsonian syndromes. PLoS One (2012) 7(4):e34891. doi:10.1371/journal.pone.0034891

109. Fischer MD, Synofzik M, Kernstock C, Dietzsch J, Heidlauf R, Schicks J, et al. Decreased retinal sensitivity and loss of retinal nerve fibers in multiple system atrophy. Graefes Arch Clin Exp Ophthalmol (2013) 251(1):235-41. doi:10.1007/s00417-012-2118-1

110. Heijl A, Leske MC, Bengtsson B, Hyman L, Bengtsson B, Hussein M, et al. Reduction of intraocular pressure and glaucoma progression: results from the Early Manifest Glaucoma Trial. Arch Ophthalmol (2002) 120:1268-79. doi:10.1001/archopht.120.10.1268

111. Glovinsky Y, Quigley H, Dunkelburger G. Retinal ganglion cell loss is size dependent in experimental glaucoma. Invest Ophthalmol Vis Sci (1991) 32:484-91.

112. Chaturvedi N, Hedley-Whyte E, Dreyer E. Lateral geniculate nucleus in glaucoma. Am J Ophthalmol (1993) 116:182-8. doi:10.1016/S0002-9394 (14)71283-8

113. Sample PA, Weinreb RN, Boynton RM. Acquired dyschromatopsia in glaucoma. Surv Ophthalmol (1986) 31(1):54-64. doi:10.1016/0039-6257(86)90051-2

114. Morgan JE. Selective cell death in glaucoma: does it really occur? $\mathrm{Br}$ J Ophthalmol (1994) 78(11):875-9; discussion 879-80. doi:10.1136/bjo.78. 11.875

115. Pearson P, Swanson WH, Fellman RL. Chromatic and achromatic defects in patients with progressing glaucoma. Vision Res (2001) 41(9):1215-27. doi:10.1016/S0042-6989(00)00311-4
116. Morgan JE. Retinal ganglion cell shrinkage in glaucoma. J Glaucoma (2002) 11:365-70. doi:10.1097/01.IJG.0000021803.38852.03

117. Yucel YH, Zhang Q, Gupta N, Kaufman PL, Weinreb RN. Loss of neurons in magnocellular and parvocellular layers of the lateral geniculate nucleus in glaucoma. Arch Ophthalmol (2000) 118:378-84. doi:10.1001/ archopht.118.3.378

118. Weber AJ, Chen H, Hubbard WC, Kaufman PL. Experimental glaucoma and cell size, density, and number in the primate lateral geniculate nucleus. Invest Ophthalmol Vis Sci (2000) 41:1370-9.

119. Weber AJ, Kaufman PL, Hubbard WC. Morphology of single ganglion cells in the glaucomatous primate retina. Invest Ophthalmol Vis Sci (1998) 39(12):2304-20.

120. Weber AJ, Harman CD. Structure-function relations of parasol cells in the normal and glaucomatous primate retina. Invest Ophthalmol Vis Sci (2005) 46(9):3197-207. doi:10.1167/iovs.04-0834

121. Neufeld AH, Liu B. Glaucomatous optic neuropathy: when glia misbehave. Neuroscientist (2003) 9(6):485-95. doi:10.1177/1073858403253460

122. Martin L, Wanger P, Vancea L, Gothlin B. Concordance of high-pass resolution perimetry and frequency-doubling technology perimetry results in glaucoma: no support for selective ganglion cell damage. J Glaucoma (2003) 12:40-4. doi:10.1097/00061198-200302000-00008

123. Sun H, Swanson WH, Arvidson B, Dul MW. Assessment of contrast gain signature in inferred magnocellular and parvocellular pathways in patients with glaucoma. Vision Res (2008) 48(26):2633-41. doi:10.1016/j. visres.2008.04.008

124. Schuman JS, Hee MR, Puliafito CA, Wong C, Pedut-Kloizman T, Lin CP, et al. Quantification of nerve fiber layer thickness in normal and glaucomatous eyes using optical coherence tomography. Arch Ophthalmol (1995) 113(5):586-96. doi:10.1001/archopht.1995.01100050054031

125. Leung CK, Chan WM, Yung WH, Ng AC, Woo J, Tsang MK, et al. Comparison of macular and peripapillary measurements for the detection of glaucoma: an optical coherence tomography study. Ophthalmology (2005) 112(3):391-400. doi:10.1016/j.ophtha.2004.10.020

126. Leung CK, Cheung CY, Weinreb RN, Qiu K, Liu S, Li H, et al. Evaluation of retinal nerve fiber layer progression in glaucoma: a study on optical coherence tomography guided progression analysis. Invest Ophthalmol Vis Sci (2010) 51(1):217-22. doi:10.1167/iovs.09-3468

127. Mwanza JC, Durbin MK, Budenz DL, Sayyad FE, Chang RT, Neelakantan A et al. Glaucoma diagnostic accuracy of ganglion cell-inner plexiform layer thickness: comparison with nerve fiber layer and optic nerve head. Ophthalmology (2012) 119(6):1151-8. doi:10.1016/j.ophtha.2011.12.014

128. Hood DC, Raza AS, de Moraes CGV, Johnson CA, Liebmann JM, Ritch R. The nature of macular damage in glaucoma as revealed by averaging optical coherence tomography data. Trans Vis Sci Technol (2012) 1(1):3. doi:10.1167/ tvst.1.1.3

129. Wang JL, Lim AS, Chiang WY, Hsieh WH, Lo MT, Schneider JA, et al. Suprachiasmatic neuron numbers and rest-activity circadian rhythms in older humans. Ann Neurol (2015) 78(2):317-22. doi:10.1002/ana.24432

130. Donadio V, Incensi A, Piccinini C, Cortelli P, Giannoccaro MP, Baruzzi A, et al. Skin nerve misfolded $\alpha$-synuclein in pure autonomic failure and Parkinson disease. Ann Neurol (2016) 79(2):306-16. doi:10.1002/ana.24567

Conflict of Interest Statement: The authors declare that the research was conducted in the absence of any commercial or financial relationships that could be construed as a potential conflict of interest.

Copyright (C) 2017 La Morgia, Di Vito, Carelli and Carbonelli. This is an open-access article distributed under the terms of the Creative Commons Attribution License (CC BY). The use, distribution or reproduction in other forums is permitted, provided the original author(s) or licensor are credited and that the original publication in this journal is cited, in accordance with accepted academic practice. No use, distribution or reproduction is permitted which does not comply with these terms. 